\title{
Effect of Distance of Sanitary Pits on the Microbial and Heavy Metal Levels in Hand Dug Well Water Samples Consumed by People Living in Akwuke, Enugu South Local Government Area of Enugu State
}

\author{
0. Okeke1, C. C. Aniobi², C. I. Akagha3, E. Ezeh", C. C. Ezejiofor ${ }^{5}$ \\ ${ }^{1}$ Plastic Production Unit, Scientific Equipment Development Institute, Akwuke-Enugu State \\ ${ }^{2}$ Department of Community Medicine, University of Nigeria, Enugu Campus, Enugu State \\ ${ }^{3}$ Chemistry Department, Federal University of Technology, Owerri, Imo State \\ ${ }^{4}$ Chemical Engineering Department, Nnamdi Azikiwe University, Awka, Anambra State \\ ${ }^{5}$ Microbiology Department, Caritas University, Enugu, Enugu State \\ Email: onyekaokeke207@yahoo.com
}

How to cite this paper: Okeke, O., Aniobi, C.C., Akagha, C.I., Ezeh, E. and Ezejiofor, C.C. (2021) Effect of Distance of Sanitary Pits on the Microbial and Heavy Metal Levels in Hand Dug Well Water Samples Consumed by People Living in Akwuke, Enugu South Local Government Area of Enugu State. Journal of Water Resource and Protection, 13, 325-339.

https://doi.org/10.4236/jwarp.2021.135020

Received: March 26, 2021

Accepted: April 26, 2021

Published: April 29, 2021

Copyright ( 2021 by author(s) and Scientific Research Publishing Inc. This work is licensed under the Creative Commons Attribution International License (CC BY 4.0).

http://creativecommons.org/licenses/by/4.0/ (c) (i) Open Access

\begin{abstract}
Studies were carried out to assess the effect of distance of sanitary pits on the microbial and heavy metal levels in hand dug well water samples consumed by people living in Akwuke, Enugu South Local government area of Enugu State, using standard biochemical and spectrophotometric analysis. The well water samples were digested with aqua-regia and four heavy metals $(\mathrm{Pb}, \mathrm{Cd}$, $\mathrm{Cu}$ and $\mathrm{Zn}$ ) were assayed in the well water samples at sampling distances of 3 , 6 and $10 \mathrm{~m}$ respectively from the sanitary pits. The range of mean bacterial counts (cfu/g) for the four detected pathogenic bacteria; $S$. aureus, Klebsiella pnemeoniae, Echerichia coli and Salmonella enteritidis were 83 - 3730, 510 870, $50-2535$ and $240-3420 \mathrm{Cfu} / \mathrm{g}$ at sampling distances of 3, 6 and $10 \mathrm{~m}$ respectively from the sanitary pits. The mean bacteria counts of the four detected pathogenic organisms in the well water sample at sampling distances of 3 and $6 \mathrm{~m}$ respectively from the sanitary pits were above the WHO recommended threshold limits for a safe drinking water. The mean bacterial counts of Salmonella enteritidis in the well water samples of sampling distance of 10 $\mathrm{m}$ from the sanitary pits was above the WHO recommended permissible limits. At sampling distances of 3, 6 and $10 \mathrm{~m}$ from the sanitary pits, the mean range of $\mathrm{Pb}, \mathrm{Cd}, \mathrm{Cu}$ and $\mathrm{Zn}$ in the well water samples were, $0.03-0.3,0.02$ $0.05,0.46-1.71$ and $1.63-7.03 \mu \mathrm{g} / \mathrm{g}$ respectively. The mean levels of $\mathrm{Pb}$ and $\mathrm{Cd}$ in the well water samples at sampling distances of 3 and $6 \mathrm{~m}$ respectively
\end{abstract}


from the sanitary pits were above their respective WHO recommended threshold limits. The mean heavy metals $(\mathrm{Cd}, \mathrm{Pb}, \mathrm{Cu}$ and $\mathrm{Zn})$ in the well water samples at sampling distances of 3,6 , and $10 \mathrm{~m}$ respectively from the sanitary pits were statistically significant at $\mathrm{p}<0.05$.

\section{Keywords}

Heavy Metals, Hand Dug Well Water, Pathogenic Bacteria, Faecal Contamination, Sanitary Pits

\section{Introduction}

Water is the most important source of life on earth and is of vital importance in human life. It is incredibly indispensable for the existence of all living organisms [1]. The quality of water is important in environmental studies because of its daily use for human consumption and its ability to transport pollutants [2]. Water is obtained from a number of sources, some of which are rain, lakes, streams, underground wells and springs. As the population of the world increases, there is the need for the supply of safe water for drinking, domestic, industrial and agricultural uses, so that healthy life can be achieved [3].

The United Nations described free access to clean water as a basic human right and one of the indices of good living [4]. Ground water is a major source of water supply, which could be found in form of borehole and well water. According to Afolabi et al. [5], ground water accounts for about $50 \%$ of water worldwide supplies. As ground water is isolated from the soil surface, most people believed that ground water should be relatively pure and free from pollutants. Although most ground water is still of high quality at some locations, however, the quality of ground water is becoming increasingly threatened especially in developing countries of the world.

Over population and unintended urbanization, unhindered exploration guidelines, and improper dumping of solid and liquid wastes enhance the infiltration of harmful substances unto the ground water resources and thus posing potential risks to the receptors [6].

According to Ullah $\mathrm{R}$ et al. [7], uncontrolled dumping of industrial wastes and the use of chemical constituents in agriculture are the major causes of ground water pollution. Additionally, due to the sanitation inadequacies especially in developing countries like Nigeria, well water sited around poor sewage systems, pit latrines and waste dumps have also been reported to affect the physical, chemical and microbial integrity of ground well water [8].

Ground water quality depends not only on natural factors such as aquifer lithology, ground water velocity, quality of recharge waters and interaction with other types of water or aquifers but also on human activities and the environment.

The ground water acquifer system once contaminated tends to remain for a 
long period of time, even if the source of pollution, being industrial or domestic waste water disposal or recycling is eliminated [1].

Contamination of ground water resources with heavy elements, metal ions and harmful micro organisms is one of the major health problems today [2]. A principal microbiological concern in ground water is the health hazard posed by faecal contamination.

According to Agunwamba J.C., and Bepule V. [9], of the four types of pathogens (viruses, bacteria, protozoa and parasite) contained in human excreta, only bacteria and viruses are likely to be small enough to be transmitted through the soil and aquifer matrix to ground water bodies.

Water is contaminated by various pathogenic microorganisms such as bacteria, fungi, viral protozoa and other biological organisms and these pathogenic agents have been implicated in various diseases that affect human health [10]. The potential ability of water to transmit microbial pathogens to a great number of people causing subsequent illness is well documented at all levels of economic development [11].

According to $\mathrm{WHO}$, about $80 \%$ of diseases are water borne due to drinking contaminated water and $3.1 \%$ deaths occur due to the consumption of unhygienic and poor-quality water in developing countries [12]. Research has shown high prevalence of water borne diseases such as cholera, diarrhea, dysentery, typhoid fever and hepatitis in developing countries which claims the lives of a hundred thousand children and adults per year [13].

Yahaya et al. [14] stated that children are most frequently affected by contaminated water and a minimum of 525,000 children worldwide die every year due to diarrhea illnesses, most of which are caused by contaminated water, poor sanitation and poor personal hygiene. Heavy metals are among notable water contaminants which are generally toxic metals with a specific density greater than 5 $\mathrm{g} / \mathrm{cm}^{3}[15]$.

Heavy metals of public health concern regarding water contamination include arsenic (AS) cadmium (Cd), nickel (Ni), mercury (Hg), Chromium (Cr), Zinc $(\mathrm{Zn})$, copper $(\mathrm{Cu})$ and lead $(\mathrm{Pb})$. The principal sources of surface and ground water contamination with heavy metals are natural processes and anthropogenic activities [16]. The rise in the concentration of heavy metal in water bodies irrespective of the origin is posing a serious health threat to human and aquatic ecosystems [14].

Heavy metals generate reactive oxygen species in living organisms, thereby causing oxidative damage [17].

Additionally, heavy metal contamination of drinking water sources has been linked with deficiencies of some essential nutrients, which culminates in compromised immunological defenses, intrauterine growth retardation, impaired psychosocial faculties and increased prevalence of upper gastro-intestinal cancers [18].

Water that has good drinking quality is of basic importance to human physiology and humans continued existence relies very much on its availability. Ground 
water quality is an indispensable factor in its usage for agricultural industrial, domestic and drinking purposes. Due to poor regulatory frame work on the part of environmental and health agencies at providing standard distance when sitting well water around sanitary pits, property owners here at Akwuke community have indulged in the habit of siting well water close to sanitary pits in a bid to conserve space, thereby compromising the health of the people that consume the well water.

Consequently, this study evaluated the effect of distance of sanitary pit on the microbial and heavy metal levels in hand dug well water samples consumed by people living within Akwuke in Enugu South Local Government Area of Enugu State.

\section{Materials and Methods}

\subsection{The Study Area}

The study was carried out in Akwuke, an agrarian community, with a lot of sand mining activity and federal government offices, situated in the community and is located in Enugu South Local Government Area of Enugu State. It lines with latitude $7^{\circ} 386.0 \mathrm{~N}$ and longitude $6^{\circ} 4921.30 \mathrm{E}$.

The topography of Akwuke is undulating. The community falls within the tropical rainforest belt of South East, Nigeria and is characterized by an average rainfall of 1570 to $1800 \mathrm{~mm}$ per annum.

The residents of the community depend mainly on ground well water sources to serve their domestic and household needs.

\subsection{Sample Collection}

Ten (10) water samples were each collected from hand dug wells at distances of 3,6 and $10 \mathrm{~m}$ respectively from sanitary pits located randomly within Akwuke community. Hence a total of thirty (30) well water samples were randomly collected between the months of November and December, 2020. The water samples were collected in clean, pre-sterilized, well labeled plastic containers. The sample containers were tightly covered and taken to the laboratory where they were stored in desiccators prior to heavy metal and microbiological analyses.

\subsection{Microbiological/Biochemical Analysis and Identification of Bacterial Isolates}

In order to identify bacteria species the microbiological techniques employed included inoculation, gram staining, colony, and morphological characterization for physical and structural features of organisms as described by Janseen P.H. [19]. Pure cultures of the isolates were subjected to various biochemical tests to determine the identity of the bacteria species. The result of each test was recorded and the probable identity of the isolates was determined by the use of Bergey's manual of determinative bacteriology [20]. Bacterial colonies were counted to obtain the viable cell count. 


\subsection{Heavy Metal Analysis}

About $0.5 \mathrm{ml}$ of each water sample was mixed with $25 \mathrm{ml}$ aqua-regia solution in the digestion tube and then digested on $120^{\circ} \mathrm{C}$ for 3 hours. The digested material was filtered into $100 \mathrm{ml}$ beaker and the solution was analyzed for the selected heavy metals using atomic absorption spectrophotometer (UNICAM Model 969) [21].

\subsection{Pollution Index Computation}

Pollution index $(\mathrm{Pi})$ is defined as the ratios of the concentration of the individual parameter against the baseline standard. It provides information contributed by individual sample parameters.

$$
\text { Pollution Index }(\mathrm{Pi})=\frac{A}{B}
$$

where $A$ is the concentration of individual parameter and $B$ is the reference standard.

The pollution index of the well water samples at distances of 3,6 and $10 \mathrm{~m}$ respectively from the sanitary pits were determined for $\mathrm{Pb}, \mathrm{Cu}, \mathrm{Cd}$ and $\mathrm{Zn}$.

\subsection{Statistical Analysis}

Data were expressed as mean \pm standard deviation and subjected to one way analysis of variance at 5\% confidence level using SPSS 22.0.

\section{Results and Discussion}

Table 1 shows that four pathogenic organisms namely, Staphylococcus aureus, Klebsiella pnemoniae, Escherichia coli and Salmonella enteritidis were isolated and detected at well water sample distances of 3 and $6 \mathrm{~m}$ respectively from the sanitary pits situated in Akwuke local government area of Enugu State.

Table 1. Biochemical characteristics of bacterial isolates at sampling distances of 3 and 6 $\mathrm{m}$ respectively from the sanitary pits.

\begin{tabular}{|c|c|c|c|c|c|c|c|c|}
\hline $\begin{array}{c}\text { Cultural } \\
\text { characteristics }\end{array}$ & Morphology & $\begin{array}{c}\text { Gram } \\
\text { staining }\end{array}$ & Glucose & indole & Coagulate & Catalase & citrate & $\begin{array}{c}\text { Most } \\
\text { probable } \\
\text { identity }\end{array}$ \\
\hline $\begin{array}{l}\text { Yellowish } \\
\text { orange } \\
\text { and slimy }\end{array}$ & $\begin{array}{l}\text { Cocci in } \\
\text { pairs }\end{array}$ & + & + & - & - & + & + & S. aureus \\
\hline $\begin{array}{l}\text { Pink, Smooth, } \\
\text { flat and irregular }\end{array}$ & $\begin{array}{l}\text { Rods in } \\
\text { single pairs } \\
\text { and clusters }\end{array}$ & - & - & + & + & + & + & $\begin{array}{c}\text { Klebsiella } \\
\text { pneumoniae }\end{array}$ \\
\hline $\begin{array}{l}\text { Red-coloured } \\
\text { with a smooth } \\
\text { serrated edge }\end{array}$ & $\begin{array}{c}\text { Rods } \\
\text { straight }\end{array}$ & - & + & + & NA & + & + & $\begin{array}{c}\text { Escherichia } \\
\text { coli }\end{array}$ \\
\hline $\begin{array}{l}\text { Creamy and } \\
\text { irregular }\end{array}$ & $\begin{array}{c}\text { Rods } \\
\text { scattered }\end{array}$ & + & - & - & - & + & - & $\begin{array}{c}\text { Salmonella } \\
\text { enteritidis }\end{array}$ \\
\hline
\end{tabular}


Table 2 shows that three pathogenic organisms namely; Staphylococcus aureus, Eschericha coli and Salmonella enteritidis were isolated and detected at a sampling distance of $10 \mathrm{~m}$ from the sanitary pits. The result of this study compared very well with the findings of Jega B.G. et al. [22] who isolated and detected Salmonella tophii, Escherichia coli, Staphylococcus aureus, Citrobacter species, Enterobacteria species and Serratia mercesscens in a public water supply in Birnin, Kebbi, Kebbi State. Adesakin T.A. et al. [10] isolated and detected a very high bacterial load of Enterobacter, Protens, Escherichia coli, Salmonella enteritidis and Shigella spp in well, borehole and tap water samples consumed by people in Samaru community, Zaria and their findings totally agreed with the results of this study.

It is therefore safe to say that the detection of $S$. aureus, E. coli, Salmonella enteritidis and Klebsiella pnemoniae well water sample distance of 3,6 and $10 \mathrm{~m}$ respectively from sanitary pits indicated faecal contamination of this water samples and therefore represents a potential health risk to the users of this water.

Adesakin T.A. et al. [10] stated that pathogenic organisms mostly find their way into ground water at high concentrations through run-offs or seepage.

The result of this study clearly shows that consumption of water from hand dug wells that are mostly shallow makes bacterial contamination of such water very likely due to the seepage of bacteria from surrounding sanitary pits into the acquifer of the well water with the level of contamination possibly increasing with decrease in distance of the well water from the sanitary pits.

Table 3 shows that the mean count of Staphylococcus aureus at sampling distances of 3, 6 and $10 \mathrm{~m}$ from the sanitary pits were 2750, 1030, and $83 \mathrm{Cfu} / \mathrm{g}$ respectively. The mean count of Klebsiella pneumoniae at well water sample distances of 3, 6 and from the sanitary pits were 870 and $510 \mathrm{Cfu} / \mathrm{g}$ respectively. The mean count of Escherichia coli at well water sampling distances of 3, 6 and $10 \mathrm{~m}$ from the sanitary pits were 2535,1760 and $50 \mathrm{Cfu} / \mathrm{g}$ respectively.

The mean count of Salmonella entertidis at well water sampling distances of 3, 6 and $10 \mathrm{~m}$ from the sanitary pits were 3420, 2510 and $240 \mathrm{Cf} \mu / \mathrm{g}$ respectively.

Table 2. Biochemical characteristics of bacterial isolates at sampling distance of $10 \mathrm{~m}$ from the sanitary pits.

\begin{tabular}{|c|c|c|c|c|c|c|c|c|}
\hline $\begin{array}{c}\text { Cultural } \\
\text { characterisitcs }\end{array}$ & Morphology & $\begin{array}{c}\text { Gram } \\
\text { staining }\end{array}$ & Glucose & indole & Coagulate & Catalase & Citrate & $\begin{array}{c}\text { Most } \\
\text { probable } \\
\text { identity }\end{array}$ \\
\hline $\begin{array}{c}\text { Yellowish } \\
\text { orange and } \\
\text { slimy }\end{array}$ & $\begin{array}{l}\text { Cocci } \\
\text { in pairs }\end{array}$ & + & + & - & - & + & + & $S$. aureus \\
\hline $\begin{array}{l}\text { Red-coloured } \\
\text { with a smooth } \\
\text { serrated edge }\end{array}$ & $\begin{array}{c}\text { Rods } \\
\text { straight }\end{array}$ & - & + & + & + & + & + & $\begin{array}{c}\text { Escherichia } \\
\text { coli }\end{array}$ \\
\hline $\begin{array}{c}\text { Creamy and } \\
\text { irregular }\end{array}$ & $\begin{array}{c}\text { Rods } \\
\text { scattered }\end{array}$ & + & - & - & - & + & - & $\begin{array}{c}\text { Salmonella } \\
\text { enteritidis }\end{array}$ \\
\hline
\end{tabular}


Table 3. Mean bacterial count (Cfu/g) at sampling distances of 3, 6 and $10 \mathrm{~m}$ respectively from the sanitary pits.

\begin{tabular}{|c|c|c|c|c|}
\hline \multirow{2}{*}{$\begin{array}{l}\text { Bacteria } \\
\text { isolates }\end{array}$} & \multicolumn{3}{|c|}{$\begin{array}{c}\text { Mean bacteria count }(\mathrm{Cf} \mu / \mathrm{g}) \text { at the determined } \\
\text { distances from the sanitary pits }\end{array}$} & \multirow{2}{*}{$\begin{array}{l}\text { Permissible } \\
\text { limits [12] }\end{array}$} \\
\hline & $3 \mathrm{~m}$ & $6 \mathrm{~m}$ & $10 \mathrm{~m}$ & \\
\hline S. aureus & $3750 \pm 600$ & $1030 \pm 2101$ & $83 \pm 12$ & $\leq 10^{2}$ \\
\hline Klebsiella pneumoniae & $870 \pm 25$ & $510 \pm 33$ & - & $\leq 10^{2}$ \\
\hline Escherichia coli & $2535 \pm 129$ & $1760 \pm 91$ & $50 \pm 15$ & $\leq 10^{2}$ \\
\hline Salmonella enteritidis & $3420 \pm 216$ & $2510 \pm 173$ & $240 \pm 22$ & $\leq 10^{2}$ \\
\hline
\end{tabular}

The mean count of $S$. aureus, Klebsiella pneumoniae, Escherichia coli and Salmonella enteritidis at sampling distances of 3 and $6 \mathrm{~m}$ respectively from the sanitary pits were above the WHO recommended permissible limits for a quality water. With the exception of Salmonella enteritidis, the mean count of the other isolated and detected bacteria at a well water distance of $10 \mathrm{~m}$ from the sanitary pits were within the recommended permissible limits for a safe drinking water. The result of Table 3 indicates that as the distance of the well water samples from the sanitary pits increased, the bacteria contamination of the well water sample decreased. This therefore implies that the distance of sited well water in any environment has a direct influence on the microbial load in such an underground water body. Because of the reduced sampling distances at 3 and $6 \mathrm{~m}$ respectively from the sanitary pits, the seepage of bacteria into the well water probably became very high due to increased faecal contamination of the acquifer of the water samples. The result of Table 3 shows therefore that the well water samples sited at distances of $3 \mathrm{~m}$ and $6 \mathrm{~m}$ respectively from the sanitary pits are not fit for human consumption due to the high faecal contamination of the samples which probably contributed to the microbial load in the well water samples being above its recommended threshold limits for a quality water.

According to World Health Organization (2011) [12] recommendations, there should be no faecal conforms in $100 \mathrm{ml}$ water and the reason for the gross contamination of the studied well water samples by the isolated and detected pathogens as observed in this study may be due to the shallowness of the well and its proximity (especially at sampling distances of $3 \mathrm{~m}$ and $6 \mathrm{~m}$ ) to the sanitary pits that consequently allowed seepage of pathogens into the water bodies.

The detected pathogens in the studied water samples have been implicated in a host of water borne infections which include diarrhea, dysentery, typhoid fever and cholera and have been complicated in mortality across the World [12].

Yahaya T.O. et al. [14] reported a higher mean bacterial count of 12,000 (Cf $\mu / \mathrm{g})$ in well water consumed in Ilaje in Lagos State, than what this study reported at the investigated sampling distances from the sanitary pits.

Lead

Result of Table 4 and Figure 1 shows that the mean levels of $\mathrm{Pb}$ in the well water sample at sampling distances of 3,6 and $10 \mathrm{~m}$ from the sanitary pits were $0.13 \pm 0.01,0.06 \pm 0.02$ and $0.03 \pm 0.01 \mu \mathrm{g} / \mathrm{g}$ respectively. 


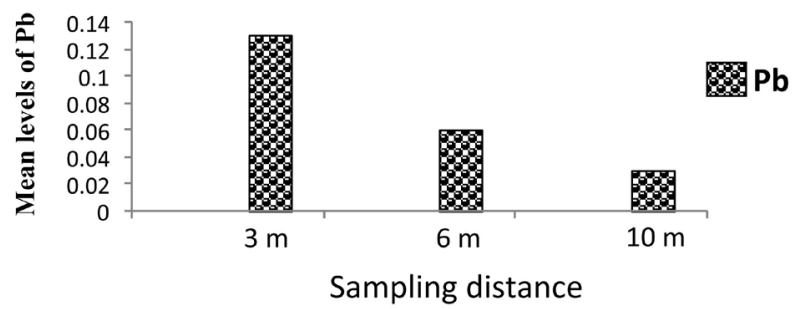

Figure 1. Bar chart representation of the mean levels of $\mathrm{Pb}$ in the water samples at determined sampling distances from the sanitary pits.

Table 4. Mean heavy metal levels ( $\mu \mathrm{g} / \mathrm{g}$ ) at well water sampling distances of 3,6 and $10 \mathrm{~m}$ respectively from the sanitary pits.

\begin{tabular}{|c|c|c|c|c|c|}
\hline \multirow[t]{2}{*}{ Metal } & \multicolumn{3}{|c|}{$\begin{array}{l}\text { Mean heavy metal concentrations }(\mu \mathrm{g} / \mathrm{g}) \text { at } \\
\text { determined sampling distances from the sanitary pits }\end{array}$} & \multirow{2}{*}{$\begin{array}{l}\text { F test, } \\
\text { p value }\end{array}$} & \multirow{2}{*}{$\begin{array}{c}{[12]} \\
\text { Permissible } \\
\text { limits }\end{array}$} \\
\hline & $3 \mathrm{~m}$ & $6 \mathrm{~m}$ & $10 \mathrm{~m}$ & & \\
\hline $\mathrm{Pb}$ & $0.13 \pm 0.01$ & $0.06 \pm 0.02$ & $0.03 \pm 0.01$ & 0.01 & 0.05 \\
\hline $\mathrm{Cd}$ & $0.05 \pm 0.01$ & $0.03 \pm 0.01$ & $0.02 \pm 0.00$ & 0.02 & 0.03 \\
\hline $\mathrm{Cu}$ & $1.71 \pm 0.21$ & $1.02 \pm 0.10$ & $0.46 \pm 0.14$ & 0.01 & 2 \\
\hline $\mathrm{Zn}$ & $7.03 \pm 0.29$ & $4.02 \pm 0.51$ & $1.63 \pm 0.30$ & 0.01 & 10 \\
\hline
\end{tabular}

The mean levels of $\mathrm{Pb}$ in the water samples were observed to decrease with increase in the sampling distance from the sanitary pits. The levels of $\mathrm{Pb}$ in the water samples at the investigated sampling distances from the sanitary pits differed significantly. The mean levels of $\mathrm{Pb}$ in the water samples at sampling distances of 3 and $6 \mathrm{~m}$ respectively from the sanitary pits were above the WHO recommended permissible limits for a safe drinking water.

The result of Table 3 clearly shows that seepage of waste fluids from the sanitary pits into the acquifer of the well water samples were highly likely especially with shallow hand dug wells and could have significantly contributed to the toxic levels of $\mathrm{Pb}$ at reduced distances $(3 \mathrm{~m}$ and $6 \mathrm{~m}$ ) from the the sanitary pits.

According to Edori O.S. and Kpee F. [23], the presence of $\mathrm{Pb}$ in underground water may be as a result of corrosion of plumbing works in households, domestic waste discharge, industrial effluent discharge, erosion, poorly constructed swage system and mining activities.

According to Jarup L. [15] the health implication of $\mathrm{Pb}$ poisoning through food and water are very severe as this include, miscarriage, poor foetus development, birth defects, kidney problems and low 1Q amongst children and alteration of the central and peripheral nervous system.

Yahaya T.O. et al. [14] reported a higher mean value of $0.25 \pm 0.01 \mu \mathrm{g} / \mathrm{g}$ for $\mathrm{Pb}$ in well water samples in Iwaya area in Lagos, than what this study obtained for $\mathrm{Pb}$ in the well water samples at the investigated sampling distances from the sanitary pits.

Cadmium

Result of Table 4 shows that the mean levels of $\mathrm{Cd}$ in the well water samples 
at water sampling distances of 3,6 and $10 \mathrm{~m}$ from the sanitary pits were $0.05 \pm$ $0.01,0.03 \pm 0.01$ and $0.02 \pm 0.00 \mu \mathrm{g} / \mathrm{g}$ respectively.

As the case with $\mathrm{Pb}$, the mean levels of $\mathrm{Cd}$ in the water samples were observed to decrease as the sampling distances from the sanitary pits were increased. The levels of $\mathrm{Cd}$ in the water samples at sampling distances of 3, 6 and $10 \mathrm{~m}$ respectively from the sanitary pits differed significantly at $\mathrm{p}<0.05$. (Figure 2)

The mean levels of $\mathrm{Cd}$ in the well water samples at a sampling distance of $3 \mathrm{~m}$ from the sanitary pits was above the WHO recommended threshold limits for a safe drinking water.

According to Yakassai I.A. et al. [24], the concentration of Cd and other heavy metals in ground water is dependent on the closeness of the water source to the roads with high traffic density, industrial activities like metal melting coal refining, oil fired power stations, electroplating plants, climatic conditions, solid waste disposal and poor sewage system. This conclusion by Yakassai I.A. et al. [24] totally agreed with the result of this study in which the mean levels of the investigated metals in the water samples were found to increase as the distance of the water samples decreased from the sanitary pits. Long-term exposure to Cd could cause kidney damage, lung cancer, hypertension and bone diseases [14].

Yahaya T.O. et al. [14] reported a comparable mean value of $0.02 \mu \mathrm{g} / \mathrm{g}$ for Cd in well water samples in Iwaya and Makoko areas in Lagos State, with what this study obtained for $\mathrm{Cd}$ in the well water samples at sampling distances of 6 and $10 \mathrm{~m}$ respectively from the sanitary pits.

Akinifesi O.J. and Akinneye J.O. [25] reported a lower mean value of $0.01 \mu \mathrm{g} / \mathrm{g}$ in well water samples in Ondo metropolis, Ondo state, than what was obtained for $\mathrm{Cd}$ in the well water samples at the investigated sampling distances from the sanitary pits.

\section{Copper}

Result of Table 4 shows that the mean levels of $\mathrm{Cu}$ in the well water samples at sampling distances of 3,6 and $10 \mathrm{~m}$ from the sanitary pits were $1.72 \pm 0.21$, $1.02 \pm 0.010$ and $0.46 \pm 0.14 \mu \mathrm{g} / \mathrm{g}$ respectively.

The mean levels of $\mathrm{Cu}$ in the water samples decreased as the sampling distance from the sanitary pits increased.

The levels of $\mathrm{Cu}$ in the well water samples at the sampling distances of 3,6 and $10 \mathrm{~m}$ respectively from the sanitary pits were statistically significant. (Figure 3 )

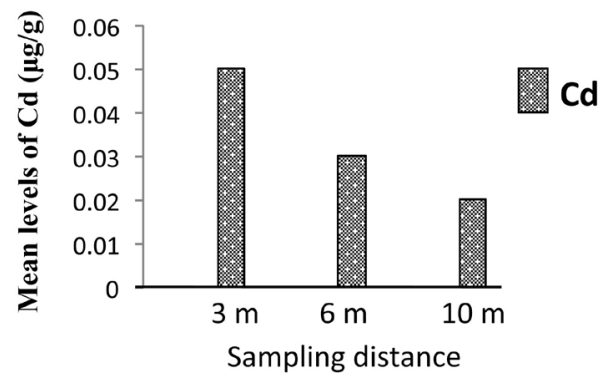

Figure 2. Bar chart representation of the mean level of $\mathrm{Cd}$ in the water samples at sampling distances of 3, 6 and $10 \mathrm{~m}$ respectively from the sanitary pits. 


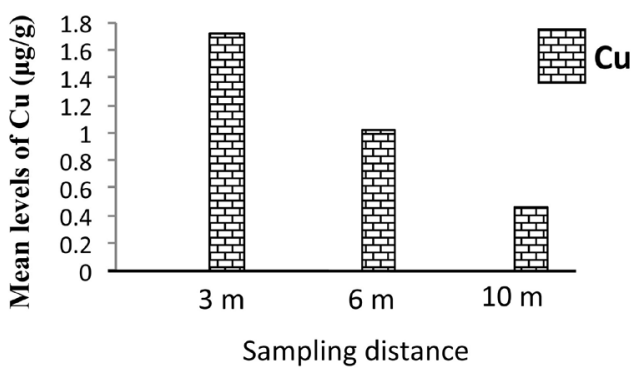

Figure 3. Bar chart representation of the mean levels of $\mathrm{Cu}$ in the well water samples at sampling distances of 3,6 and $10 \mathrm{~m}$ respectively from the sanitary pits.

The mean levels of $\mathrm{Cu}$ in the well water samples at the investigated sampling distances from these sanitary pits were within WHO recommended threshold limits for a safe drinking water.

Yahaya T.O. et al. [14] reported a mean value of $0.48 \mu \mathrm{g} / \mathrm{g}$ for $\mathrm{Cu}$ in the well water samples in Makoko area of Lagos-South West Nigeria, which compared very well with what this study obtained for $\mathrm{Cu}$ in the well water samples at sampling distance of $10 \mathrm{~m}$ from the sanitary pits.

Nwoke I.B. and Edori E.S. [26] obtained a lower mean value of $0.05 \mu \mathrm{g} / \mathrm{g}$ for $\mathrm{Cu}$ in the borehole water samples in Ikono urban in Akwa-Ibom State, than what this study got for $\mathrm{Cu}$ in the well water samples at the investigated sampling distance from the sanitary pits.

Copper is important in the formation of the foetus, building of man's immune system, development of the brain, transmission of message by the neuron and anti oxidative properties [23].

According to United States Environmental Protection Agency (2005) [27], at high concentration in the human body, copper causes abnormal copper retention in the liver (Wilson disease), irritation of the intestine and kidney damage.

\section{Zinc}

Result of Table 4 shows that the mean levels of $\mathrm{Zn}$ in the well water samples at sampling distances of 3, 6 and $10 \mathrm{~m}$ from the sanitary pits were $7.03 \pm 0.29,4.02$ \pm 0.51 and $1.63 \pm 0.30 \mu \mathrm{g} / \mathrm{g}$ respectively.

The mean levels of $\mathrm{Zn}$ in the water samples decreased with increase in sampling distance from the sanitary pits.

The levels of $\mathrm{Zn}$ in the water samples at the investigated sampling distance of 3,6 and $10 \mathrm{~m}$ respectively from the sanitary pits were statistically significant. The mean levels of $\mathrm{Zn}$ in the water samples at the investigated sampling distances from the sanitary pits were within the WHO recommended threshold limits for a safe drinking water. (Figure 4)

Yahaya T.O. et al. [14] reported a lower mean value of $2.53 \mu \mathrm{g} / \mathrm{g}$ for $\mathrm{Zn}$ in the well water samples in Makoko area in Lagos, than what this study reported for $\mathrm{Zn}$ in the studied well water samples at sampling distances of 3 and $6 \mathrm{~m}$ respectively from the sanitary pits.

However, the reports of Yahaya T.O. et al. [14] for $\mathrm{Zn}$ in the well water samples in Makoko, Ileja and Ileja areas of Lagos was higher than the mean value 


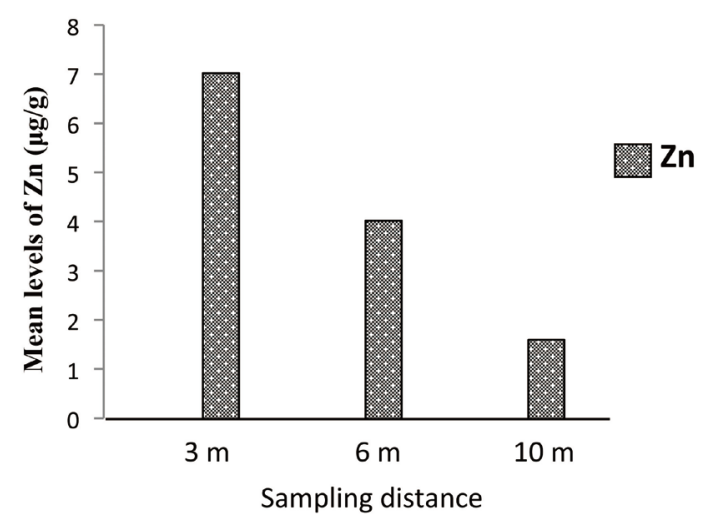

Figure 4. Bar chart representation of the mean levels of $\mathrm{Zn}$ in the well water samples at sampling distances of 3,6 and $10 \mathrm{~m}$ respectively from the sanitary pits.

obtained for $\mathrm{Zn}$ in the well water samples at a sampling distance of $10 \mathrm{~m}$ from the sanitary pits.

Although zinc is not a human carcinogen, however excessive exposure to it through the food chain could lead to vomiting dehydration, abdominal pain, lethargy dizziness and apoptosis of the brain [28].

The contamination/pollution index values according to Lacatusu R. [29]: $<0.1$ is very slightly contaminated; $0.10-0.25$ is slightly contaminated; $0.26-0.5$ is moderately contaminated; $0.51-0.75$ is severally contaminated; $0.76-1.00$ is very severely contaminated; $1.1-20$ is slightly polluted; $2.1-4.0$ is moderately polluted; $4.1-8.0$ is severely polluted; $8.1-16.0$ is very severely polluted and $>16$ is excessively polluted.

Result of Table 5 shows that the well water samples at sampling distance of 3 $\mathrm{m}$ from the sanitary pits was severely polluted with $\mathrm{Pb}$; slightly polluted with $\mathrm{Pb}$ at a sampling distance of $6 \mathrm{~m}$ from the sanitary pits and severely contaminated with $\mathrm{Pb}$ at a sampling distance of $10 \mathrm{~m}$ from the sanitary pits. Apart from the proximity of the well water samples to the sanitary pits, other anthropogenic activities like fertilizer application taking place within the studied environment could have significantly contributed to the increased pollution index values of $\mathrm{Pb}$ at sampling distances of 3 and $6 \mathrm{~m}$ respectively from the sanitary pits.

Pollution index values of $\mathrm{Cd}$ in the well water samples at sampling distances of 3, 6 and $10 \mathrm{~m}$ respectively from the sanitary pits indicated a moderate to very severe contamination of the water samples with $\mathrm{Cd}$. The health implication of this development on the residents of the community who consumes this water daily cannot be over emphasized.

The pollution index values of $\mathrm{Cu}$ and $\mathrm{Zn}$ in the water samples at sampling distances of 3,6, and $10 \mathrm{~m}$ respectively from the sanitary pits indicated a slight to very severe contamination of the water samples with $\mathrm{Cu}$ and $\mathrm{Zn}$.

Anake W.V. et al. [30] reported a higher pollution index values of 7.50 for $\mathrm{Pb}$ in drinking and ground water sources in Ofa, Ogun State Nigeria than what was obtained for the metal in the studied well water samples at sampling distances of 3,6 and $10 \mathrm{~m}$ respectively from the sanitary pits. 
Table 5. Pollution index of the heavy metals in the well water samples at sampling distances of 3, 6 and $10 \mathrm{~m}$ respectively from the sanitary pits.

\begin{tabular}{cccc}
\hline \multirow{2}{*}{ Metal } & \multicolumn{2}{c}{ Pollution index at the determined sampling distances from the sanitary pits. } \\
\cline { 2 - 4 } & $3 \mathrm{~m}$ & $6 \mathrm{~m}$ & $10 \mathrm{~m}$ \\
\hline $\mathrm{Pb}$ & 6.5 & 1.2 & 0.6 \\
$\mathrm{Cd}$ & 1 & 0.6 & 0.4 \\
$\mathrm{Cu}$ & 0.85 & 0.61 & 0.29 \\
$\mathrm{Zn}$ & 0.70 & 0.40 & 0.16 \\
\hline
\end{tabular}

\section{Conclusions}

The study shows that closeness of well water sources to sanitary pits significantly increases the faecal contamination of such well water and thereby increasing the presence of pathogenic organisms in the well water. For example, pathogenic bacteria such as Staphylococcus aureus, Klebsiella pneumoniae, Escherichia coli and Salmonella enteritidis were isolated and detected in the well water samples at sampling distances of 3,6 and $10 \mathrm{~m}$ respectively from the sanitary pits. However, the mean bacteria count of these detected bacteria showed that they were above the WHO recommended threshold limits for safe drinking water, especially at sampling distances of 3 and $6 \mathrm{~m}$ respectively from the sanitary pits. The result, therefore, indicates a serious health risk to the continued consumption of the well water at the proximal distances of 3 and $6 \mathrm{~m}$ respectively from the sanitary pits.

The proximity of the sanitary pits to the often shallow hand dug well samples which increased the leachates of fluid wastes from the sanitary pits into the acquifer of the well water samples along with other anthropogenic activities like fertilizer application within the studied environments could have been the reason for the high mean levels of $\mathrm{Pb}$ and $\mathrm{Cd}$ in the water samples.

The mean levels of $\mathrm{Cd}$ and $\mathrm{Pb}$ in the well water samples at sampling distances of 3 and $6 \mathrm{~m}$ respectively from the sanitary pits were above the WHO recommended permissible limits for safe drinking water. The mean levels of the four investigated metals in the well water samples at a sampling distance of $10 \mathrm{~m}$ from the sanitary pits were within their respective threshold limits for safe drinking water.

The pollution index values of the investigated heavy metals showed that the well water samples were severely contaminated with $\mathrm{Cd}$ at a sampling distance of $3 \mathrm{~m}$ from the well sanitary pits while the well water samples were slight to severely polluted with $\mathrm{Pb}$ at sampling distances of $3 \mathrm{~m}$ and $6 \mathrm{~m}$ respectively from the sanitary pits. The countless number of people gets water borne infections on daily basis, sometimes leading to fatalities in developing countries like Nigeria, because of poor access to safe quality water, therefore, stricter enforcement of regulation towards ensuring that well water or borehole water are sited at a reasonable of $10-15 \mathrm{~m}$, from sanitary pits is one way of increasing the assessment of people in rural communities to safe water sources that are fit for human con- 
sumption and also with very minimal levels of biological and non-biological contaminants.

\section{Acknowledgements}

The authors of this research wish to express their gratitude to the head of Springboard laboratories ltd at Awka, Anambra State for co-operating fully with our team during the period of the analysis at their laboratory.

\section{Conflicts of Interest}

The authors declare no conflicts of interest regarding the publication of this paper.

\section{References}

[1] Ojekunle, Z.O., Adeyemi, A.A, Taiwo, A.M., Ganiyu, S.A. and Balogun, M.A. (2020) Assessment of the Physiochemical Properties of Ground Water within Selected Industrial Areas in Ogun State, Nigeria. Environmental Pollutants and Bioavailability, 32, 100-113. https://doi.org/10.1080/26395940.2020.1780157

[2] Augustine, A.U., Obonde, G.A., Staislans, O.O. and Bosede, A.B. (2018) Heavy Metals and Bacteriological Analyses of Water Samples from Hand-Dug Wells in Lafia Metropolis. Open Access Journal of Chemistry, 2, 11-20.

[3] Elinje, C.M., Itodo, A.U., Pevi, I.J., Burnin-Yari, V.A. and Mbongo, A.N. (2011) Assessment of Heavy Metals Concentrations in Borehole Waters in Aliero Community of Kebbi State. Advances in Applied Research, 2, 279-282.

[4] Centre for Disease Control (2012) Global Water, Sanitation and Hygiene (WAS). https://www.cdc.gov/healthywater/globalburden.html

[5] Afolabi, T.A., Ogboneke, C.C., Ogunkunle, O.A. and Bamiro, F.O. (2012) Comparative Assessment of the Potable Quality of Water from Industrial Urban and Rural Parts of Lagos, Nigeria. Journal of Science, 14, 221-232.

[6] Pandey, S.K. and Tiwari, S. (2009) Physicochemical Analysis of Ground Water of Selected Area of Ghazipur City: A Case Study. Natural Science, 7, 17-20.

[7] Ullah, R., Naseem, R. and Qadir, A. (2009) Assessment of Ground Water Contamination in an Industrial City of Slakolt. Pakistan African Journal of Environmental Science and Technology, 3, 429-446.

[8] Muta'al Hellandendu, J. (2012) Health Implications of Water Scarcity in Nigeria. European Science Journal, 8, 111-117.

[9] Agunwamba, J.C. and Bepule, V. (2014) Physiochemical and Microbial Parameters of Water from Hand-Dug Wells from Myane, a Suborb of Obuasi Ghana. International Journal of Science and Technology, 3, 347-351.

[10] Adesakin, T.A., Oyewole, A.T., Bayereo, U., Mohammed, A.N., Aduwo, I.A, Ahmed, P.Z., Abubakar, N.D. and Barje, I.B. (2020) Assessment of Bacteriological Quality and Physicochemical Parameters of Domestic Water Sources in Samaru Community, Zaria, North West Nigeria. Heliyon, 6, 501-513.

https://doi.org/10.1016/j.heliyon.2020.e04773

[11] Abednego, M.M., Mbaruk, A.S., John, N.M. and John, M.M. (2013) Water Borne Bacterial Pathogens in Surface Water Nairobi River and Health Implications to Communities. World Applied Science, 3, 117-126.

[12] World Health Organization (2011) Guidelines for drinking Water Quality. 565th 
Edition, WHO Library, Cataloging Publications, Switzerland.

[13] Raji, M.O. and Ibrahim, Y.E. (2011) Prevalence of Water Borne Infection in North Western, Nigeria: A Respective Study. Journal of Public Health Epidemiology, 3, 382-385.

[14] Yahaya, T.O., Oladele, E.O., Fatodu, I.A., Aldulazeez, A. and Yusuf, I.Y. (2020) The Concentration and Health Risk Assessment of Heavy Metals and Micro-Organisms in the Ground Water of Lagos, South West-Nigeria. Journal of Advanced Environment and Health Research, 8, 225-233.

[15] Jarup, L. (2003) Hazard of Heavy Metal Contamination. British Medical Bulletin, 68, 167-182. https://doi.org/10.1093/bmb/ldg032

[16] Nevaeedullah, M.Z., Hoshmi C.Y., Hui S. and Yingtu C. (2004) Concentrations and Human Health Risk Assessment of Selected Heavy Metals in Surface Water of the Siling Reservoir Water Shed in Zhejiang Province, China. Polish Journal Environmental Studies, 23, 801-811.

[17] Rehman K., Fatima F., Waheed I. and Akash M.S.H. (2017) Prevalence of Exposure of Heavy Metals and Their Impact on Health. Journal of Cell Biochemistry, 119, 157-184.

[18] Arora, M., Kiran, B, Rani, S., Kaur, B. and Mittal, N. (2008) Heavy Metal Accumulation in Vegetables Irrigated with Water from Different Sources. Food Chemistry, 111, 811-815. https://doi.org/10.1016/j.foodchem.2008.04.049

[19] Janseen, P.H. (2006) Identifying the Dormant Soil Bacteria Taxa in Libraries of 165-RNA, and 165 rRNA Genes. Applied Environmental Microbiology, 72, 1719-1728. https://doi.org/10.1128/AEM.72.3.1719-1728.2006

[20] Forbes B., Davel A., Salun F. and Alice A. (2002) Bahey and Scotts Diagnosis Microbiology. 11th Edition, Mosby, St. Louis, 222-229.

[21] Adelaja, O. A., Okoronkwo, A.E. and Abass, I.T. (2012) Investigation of Heavy Metals Binding to Jatropha Curcas husk. Nature and Science, 10, 1-6.

[22] Jega, B.G., Abaukar, U. and Marge, S.S. (2017) Detection of Coliform from Public Water Supply in Birnin-Kebbi Metropolis, Kebbi State, North-Western Nigeria. ATBU Journal of Science, Technology and Education, 5, 96-103.

[23] Edori, O.S. and Kpee, F. (2016) Physicochemical and Heavy Metal Assessment of Water Samples from Borehole near Some Abattoirs in Port-Harcourt, Rivers State. American Chemical Science Journal, 14, 1-8. https://doi.org/10.9734/ACSJ/2016/22525

[24] Yakassai, I.A. and Salawu, F. and Musa, H. (2004) The Concentrations of lead in Ahmadu Bello University Dan. Raw, Treated (Tap) and ABOCONS Pure Water. Journal of Chemical Education, 1, 86-90.

[25] Akinifesi, O.J. and Akinneye, J.O. (2019) Comparative Bacteriological and Heavy Metal Toxicity Evaluation of Ground Water Wells Proximal to Pollution Receiving Streams in Ondo City, Nigeria. The Open Microbiology Journal, 13, 315-323. https://doi.org/10.2174/1874285801913020315

[26] Nwoke I.B. and Edori E.S. (2020) Concentration of Heavy Metals in Borehole Water from Ikono Urban, Local Government Area, Akwa-Ibom State, Nigeria. International Journal of Advanced Research in chemical science, 7, 27-33. https://doi.org/10.20431/2349-0403.0701005

[27] United States Environmental Protection Agency (2005) Ground Water Current Standards. National Primary Drinking Water Standards. United States Environmental Protection Agency, Washington DC, 1-12. 
[28] Plum, L.M, Rink, L. and Haase, H. (2010) The Essential Toxin. Impact of Zinc on Human Health. International Journal of Environmental Research and Public Health, 7, 1342-1365. https://doi.org/10.3390/ijerph7041342

[29] Lacatusu, R. (2000) Appraising Levels of Soil Contamination and Pollution with Heavy Metals. European Soil Bureau Research Report, 4, 393-402.

[30] Anake, W.V., Benson, N.U, Akinsiku, A.A., Ehi-Eromosele, C.O. and Adeniyi, I.O. (2014) Assessment of Trace Metals in Drinking and Ground Water Sources in Ota, Nigeria. International Journal of Scientific and Research Publications, 4, 1-4. 